\title{
KORELASI DERAJAT OBESITAS DENGAN RISIKO TERJADINYA OBSTRUCTIVE SLEEP APNEA (OSA) PADA REMAJA SMA NEGERI DI KECAMATAN BANDA SAKTI KOTA LHOKSEUMAWE 2018
}

\author{
Mauliza $^{1}$, Nur Fardian ${ }^{2}$, Surya Gunawan ${ }^{3}$ \\ ${ }^{1}$ Bagian Ilmu Kesehatan Anak, Fakultas Kedokteran, Universitas Malikussaleh \\ ${ }^{2}$ Bagian Ilmu Gizi, Fakultas Kedokteran, Universitas Malikussaleh \\ ${ }^{3}$ Program Studi Kedokteran Fakultas Kedokteran, Universitas Malikussaleh
}

Corresponding Author:suryagunawan13@gmail.com

\begin{abstract}
Abstrak
Obstructive Sleep Apnea (OSA) merupakan suatu kelainan pernapasan selama tidur yang ditandai dengan obstruksi saluran napas atas parsial atau obstruksi total intermiten yang mengganggu ventilasi dan pola tidur normal. Terdapat berbagai faktor yang bisa menyebabkan OSA. Obesitas adalah salah satu faktor risiko terjadinya OSA. Tujuan penelitian ini untuk mengetahui adakah korelasi antara derajat obesitas dengan risiko terjadinya obstructive sleep apnea pada remaja SMAN di Kecamatan Banda Sakti Kota Lhokseumawe. Jenis penelitian ini adalah analitik dengan pendekatan cross sectional. Populasi dalam penelitian ini adalah seluruh siswa-siswi obesitas yang bersekolah di SMAN Kecamatan Banda Sakti dengan jumlah sampel 71 orang diambil dengan teknik total sampling. Data dikumpulkan melalui kuesioner Berlin, Indeks Massa Tubuh (IMT), dan di analisis secara univariat dan bivariat. Hasil statistik menggunakan uji somers'd menunjukkannilai $p=0,000(\alpha=0,05)$. Kesimpulan penelitian ini adalah Ho ditolak artinya terdapat korelasi antara derajat obesitas dengan risiko terjadinya obstructive sleep apnea pada remaja SMAN di Kecamatan Banda Sakti Kota Lhokseumawe.
\end{abstract}

Kata Kunci : obstructive sleep apnea, obesitas, remaja

\section{Correlation Of The Degree Of Obesity With The Risk Of Obstructive Sleep Apnea (OSA) In Adolescents In Public High School In Banda Sakti Subdistrict, Lhokseumawe City 2018}

\begin{abstract}
Obstructive Sleep Apnea (OSA) is a respiratory disorder during sleep characterized by partial airway obstruction or intermittent total obstruction which interferes with normal ventilation and sleep patterns. There are various factors that can cause OSA. Obesity is one of the risk factors for OSA. The purpose of this study is to find out is there a correlation between the degree of obesity and the risk of obstructive sleep apnea in adolescents of SMAN in Banda Sakti Subdistrict, Lhokseumawe City. This type of research is analytic with cross sectional approach. The population in this study were all obese students attending SMAN Banda Sakti District with a sample of 71 people taken by total sampling technique. Data was collected through the Berlin questionnaire, Body Mass Index (BMI), and analyzed by univariate and bivariate. Statistical results using the somers'd test show $p=0,000(\alpha=0,05)$. The conclusion of this study is that Ho is rejected, meaning that there is a correlation between the degree of
\end{abstract}


obesity and the risk of obstructive sleep apnea in adolescents of SMAN in Banda Sakti Subdistrict, Lhokseumawe City.

Keywords: obstructive sleep apnea, obesity, adolescents

\section{PENDAHULUAN}

Obesitas merupakan masalah gizi berlebih yang sering dijumpai pada anak di seluruh dunia. Obesitas pada anak merupakan konsekuensi dari asupan kalori yang melebihi jumlah kalori yang dilepaskan atau dibakar melalui proses metabolisme di dalam tubuh. ${ }^{22}$

Menurut de Onis, prevalensi anak usia sekolah dengan obesitas di negara sedang berkembang paling banyak didapatkan di Amerika Latin dan Karibia (4,4\%), kemudian Afrika (3,9\%), dan Asia (2,9\%). Tetapi secara mutlak, jumlah terbesar ada di Asia karena lebih dari 60\% (atau 10,6 juta jiwa) tinggal di kawasan ini. ${ }^{11}$

Berdasarkan Riset Kesehatan Dasar (Riskesdas) 2007 hingga 2013 persentase obesitas pada anak sekolah semakin meningkat. Riskesdas 2010 menunjukkan persentase obesitas pada kelompok umur 6-12 tahun sebesar 9,2\%. Tahun 2013 prevalensi obesitas di Indonesia pada kelompok umur 5 sampai 12 tahun sebesar 18,8\%, untuk kelompok umur 13 sampai 15 tahun sebesar 10,8\%, dan kelompok umur 16 sampai 18 tahun sebesar 7,3\%. ${ }^{6}$

Data Riskesdas 2007 menyatakan bahwa prevalensi paling tinggi laki-laki dengan kelompok umur usia 6 sampai 14 tahun dengan berat badan lebih di Sumatera Selatan $(16,0 \%)$ dan anak perempuan di Nanggroe Aceh Darussalam (12,0\%). Hasil Riset Kesehatan Dasar Nasional (Riskesdasnas) tahun 2010, prevalensi obesitas pada anak umur 13-15 tahun adalah 2,5\%. Ada 15 provinsi yang memiliki prevalensi obesitas pada anak 13-15 tahun di atas prevalensi nasional, yaitu Provinsi Sumatera Utara, Sumatera Barat, Jambi, Bengkulu, Kepulauan Bangka Belitung, DKI Jakarta, Jawa Tengah, DI Yogyakarta, Banten, Bali, Kalimantan Selatan, Kalimantan Timur, Sulawesi Utara, Sulawesi Tenggara dan Papua. Untuk prevalensi obesitas pada anak 16-18 tahun adalah 1,4\%. Terdapat 11 provinsi yang memiliki prevalensi obesitas pada anak 16-18 tahun di atas prevalensi nasional, yaitu Provinsi Kepulauan Bangka Belitung, Kepulauan Riau, DKI Jakarta, Jawa Barat, DI Yogyakarta, Jawa Timur, Kalimantan Selatan, Sulawesi Utara, Gorontalo, Papua Barat dan Papua. ${ }^{8}$

Berdasarkan data Dinas Kesehatan kota Lhokseumawe jumlah obesitas untuk anak usia sekolah didapatkan paling tinggi di Kecamatan Banda Sakti sebesar 36 orang pada tahun 2016 dan 20 orang pada tahun 2017. Untuk Kecamatan Muara Dua didapatkan 3 orang obesitas pada tahun 2016 dan 34 orang pada tahun $2017 .^{4}$ 
Obesitas juga merupakan salah satu penyebab yang dapat menurunkan kualitas sumber daya manusia di masa mendatang. Obesitas selain dapat menyebabkan meningkatnya angka kesakitan dan kematian juga menyebabkan timbulnya berbagai penyakit salah satunya adalah penyakit gangguan pernapasan saat tidur yaitu Obstructive Sleep Apnea (OSA). ${ }^{18}$

Obstructive Sleep Apnea didefinisikan sebagai suatu kelainan pernapasan selama tidur yang ditandai dengan obstruksi saluran napas atas parsial berkepanjangan atau obstruksi total intermiten yang menganggu ventilasi dan pola tidur normal. OSA tidak hanya ditemukan pada dewasa, tetapi juga pada anak-anak dan remaja. ${ }^{15}$

Obstructive sleep apnea sering terjadi pada remaja dan sering kali dianggap normal, akan tetapi memiliki tingkat morbiditas yang serius. Obstructive sleep apnea sering ditandai dengan sulit bernapas sewaktu tidur dan ditandai dengan gejala pada siang hari yaitu mengantuk yang berlebihan, dan juga dapat menyebabkan penurunan kualitas belajar dan gangguan tumbuh kembang. ${ }^{1}$

Angka kejadian OSA telah diteliti di beberapa negara. Di Amerika Serikat, angka kejadian OSA sebesar 1 sampai 3\% dengan persentase tertinggi terdapat pada kelompok usia pra-sekolah. Pada anak-anak di India, angka kejadiannya sebesar 2 hingga 5\%, dan pada anak-anak di Cina didapatkan prevalensi sebesar 5,8\% untuk laki-laki dan 3,8\% untuk perempuan. $^{15}$

Di Indonesia sendiri masih kurang penelitian berskala nasional yang memperhatikan gangguan tidur yang fatal ini. Akan tetapi menurut penelitian Supriyanto et al, mendapatkan kejadian OSA di Indonesia sebesar 31,6\% pada kelompok umur 5 sampai 13 tahun berupa habitual snoring sebesar 5,2\% dan occasional snoring sebesar 26,4\% Mengingat struktur rahang Ras Asia yang lebih sempit, dicurigai indonesia memiliki lebih banyak penderita OSA. $^{16}$

OSA masih merupakan penyakit yang menyebabkan tingkat mortalitas dan morbiditas yang cukup tinggi. Apabila dibiarkan, OSA dapat menyebabkan berbagai komplikasi seperti gangguan kardiovaskuler, metabolik, dan neuroendokrin. ${ }^{9}$

Tujuan penelitian ini adalah untuk mengetahui adakah korelasi antara derajat obesitas dengan risiko terjadinya OSA pada remaja SMAN di Kecamatan Banda Sakti Kota Lhokseumawe pada bulan Mei sampai Agustus tahun 2018. 


\section{METODE}

Metode penelitian yang dilakukan adalah jenis penelitian analitik dengan pendekatan cross sectional. Populasi dalam penelitian ini adalah seluruh siswa siswi obesitas dan bersekolah di SMAN yang ada di Kecamatan Banda Sakti Kota Lhokseumawe 2018 yang berjumlah 71 orang. Penelitian ini akan dilakukan mulai bulan Mei 2018 sampai Agustus 2018. Teknik pengambilan sampel pada penelitian ini menggunakan non-probability sampling dengan cara sampel jenuh atau total sampling, sehingga didapatkan 71 orang sebagai sampel. Sampel yang diambil adalah yang memenuhi kriteria inklusi dan ekslusi sebagai berikut: 1) Anak yang berusia 15 sampai 18 tahun yang obesitas dan bersekolah di SMA Kecamatan Banda Sakti kota Lhokseumawe; 2) Anak yang tercatat sebagai siswa atau siswi di SMA Kecamatan Banda Sakti kota Lhokseumawe; 3) Hadir pada saat penelitian; 4) Memiliki teman tidur, orang tua, atau keluarga terdekat yang bersedia membantu dalam pengisian kuisioner. Krsiteria ekslusi: 1) Anak yang memiliki penyakit yang mempengaruhi berat badan dan tinggi badan (seperti kifosis dan lainnya); 2) Anak yang tidak bersedia menjadi sampel penelitian; 3) Anak yang memilki riwayat OSA pada keluarga; 4) Anak yang memiliki memiliki riwayat penyakit seperti rinitis, polip nasi.

Variabel penelitian adalah derajat obesitas sebagai variabel independen dan Risiko obstructive sleep apnea sebagai variabel dependen. Instrumen yang digunakan berupa kuisioner berlin untuk mengetahui risiko obstructive sleep apnea. Pengukuran berat badan dan tinggi badan dengan menggunakan timbangan berat badan dan microtoise untuk mendapatkan nilai IMT. Pada penelitian ini digunakan uji Sommers'd. Jika berdasarkan hasil uji didapatkan nilai $\mathrm{p}<0,05$, maka terdapat hubungan antara kedua variabel, sedangkan jika nilai $\mathrm{p}>0.05$ maka tidak ada hubungan antara kedua variabel.

\section{HASIL PENELITIAN}

Tabel 1 Distribusi Frekuensi Berdasarkan Jenis Kelamin Dan Derajat Obesitas

\begin{tabular}{cll}
\hline Karakteristik & Jumlah (n) & Persentase (\%) \\
\hline Jenis Kelamin & & \\
Laki-laki & 30 & 42,3 \\
Perempuan & 41 & 57,7 \\
Derajat Obesitas & & \\
Derajat 1 & 42 & 59,2 \\
Derajat 2 & 29 & 40,8 \\
\hline
\end{tabular}


Tabel 5.1 menunjukkan bahwa jenis kelamin dan derajat obesitas pada responden SMAN di Kecamatan Banda Sakti Kota Lhokseumawe dengan jenis kelamin laki-laki berjumlah 30 orang $(42,3 \%)$ dan jenis kelamin perempuan berjumlah 41 orang $(57,7 \%)$, dan derajat obesitas 1 berjumlah 42 orang $(59,2 \%)$ dan derajat obesitas 2 berjumlah 29 orang $(40,8 \%)$.

Tabel 2 Karakteristik Responden Berdasarkan Risiko Obstructive Sleep Apnea Dan Jenis Kelamin

\begin{tabular}{ccc}
\hline Karakteristik Risiko OSA & Jumlah (n) & Persentase (\%) \\
\hline Risiko Rendah & & \\
Laki-laki & 15 & 46,9 \\
Perempuan & 17 & 53,1 \\
Risiko Tinggi & & 38,5 \\
Laki-laki & 15 & 61,5 \\
Perempuan & 24 & \\
\hline
\end{tabular}

Tabel 5.2 menunjukkan bahwa risiko obstructive sleep apnea pada responden SMAN di Kecamatan Banda Sakti Kota Lhokseumawe dengan risiko rendah pada laki-laki berjumlah 15 orang $(46,9 \%)$ dan pada perempuan berjumlah 17 orang $(53,1 \%)$ sedangkan risiko tinggi untuk laki-laki berjumlah 15 orang $(38,5 \%)$ dan pada perempuan berjumlah 24 orang $(61,5 \%)$.

Grafik 1 Korelasi Antara Derajat Obesitas Dengan Risiko Terjadinya Obstructive Sleep Apnea Pada Remaja SMAN Di Kecamatan Banda Sakti Kota Lhokseumawe 2018 


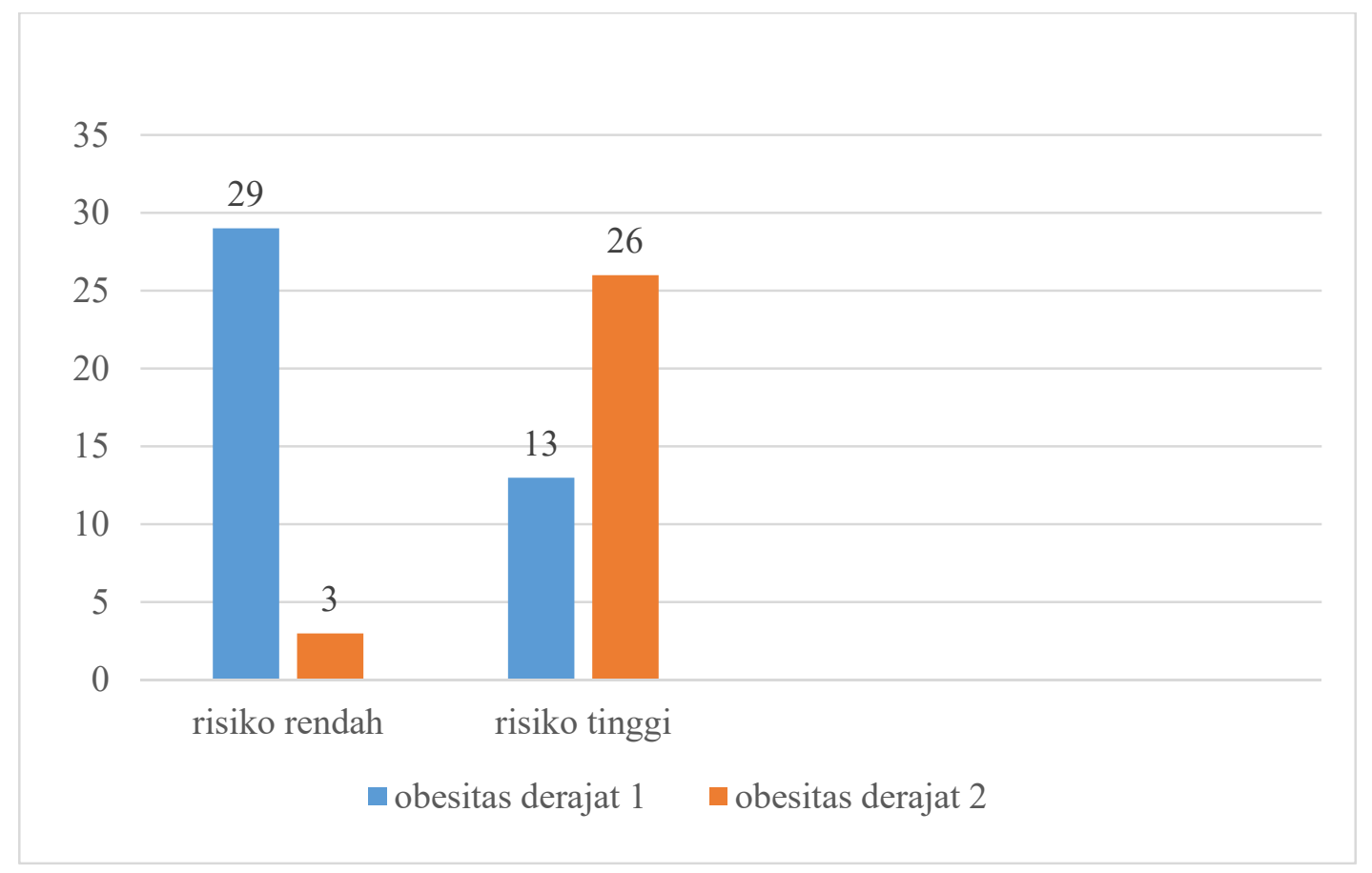

Tabel 3 Analisis Korelasi Antara Derajat Obesitas Dengan Risiko Terjadinya Obstructive Sleep Apnea Pada Remaja SMAN di Kecamatan Banda Sakti Kota Lhokseumawe

\begin{tabular}{|c|c|c|c|c|c|c|}
\hline & $\begin{array}{l}\text { Risiko } \\
\text { Rendah }\end{array}$ & $\begin{array}{l}\text { Risiko } \\
\text { Tinggi }\end{array}$ & Total & Nilai z & Nilai $\alpha$ & $P$ Value \\
\hline Obesitas & 29 & 13 & 42 & & & \\
\hline Derajat 1 & & & & 6,202 & 0,05 & 0,000 \\
\hline $\begin{array}{l}\text { Obesitas } \\
\text { Derajat } 2\end{array}$ & 3 & 26 & 29 & & & \\
\hline Total & 32 & 39 & 71 & & & \\
\hline
\end{tabular}

Berdasarkan Grafik 5.1 dapat diketahui bahwa semakin tinggi derajat obesitas maka semakin tinggi risiko terjadinya obstructive sleep apne, dan pada Tabel 5.3 dapat diketahui bahwa dari hasil analisis statistik menggunakan Uji Somers'd menunjukkan nilai $P \quad 0,000$. Hal tersebut menunjukkan berarti H0 ditolak artinya terdapat korelasi antara derajat obesitas dengan risiko terjadinya obstructive sleep apnea pada remaja SMAN di Kecamatan Banda Sakti Kota Lhokseumawe tahun 2018.

\section{PEMBAHASAN}

Berdasarkan hasil penelitian ini didapatkan bahwa jenis kelamin yang mengalami obesitas pada subjek penelitian laki-laki adalah 30 orang sedangkan pada perempuan adalah 41 orang. Berdasarkan hasil penelitian ini didapatkan perbedaan obesitas pada laki-laki dan 
perempuan, hal ini dikarenakan perempuan memiliki risiko lebih tinggi mengalami obesitas daripada laki-laki. Hal yang dikatakan terlibat dalam peningkatan berat badan adalah fungsi hormonal dalam tubuh. Peningkatan berat badan pada perempuan secara tidak langsung berhubungan dengan hormon estrogen. ${ }^{7}$ Estrogen telah lama diketahui menjadi faktor utama dalam regulasi metabolisme adiposit dan deposisi lemak dalam sel adiposit. Saat ini estogen telah terbukti memainkan peran penting pada proses adipogenesis. Estrogen bisa mempengaruhi sel adiposit secara tidak langsung dengan memodulasi selera makan atau penggunaan energy. ${ }^{20}$

Penelitian yang dilakukan oleh Wiwied \& Lintang $(2012)^{14}$ menyatakan yaitu proporsi kejadian obesitas pada remaja perempuan lebih tinggi dari pada laki-laki. Perempuan mempunyai kecenderungan lebih besar untuk mengalami obesitas. Remaja perempuan lebih banyak menyimpan kelebihan energinya sebagai lemak simpanan, sedangkan laki-laki menggunakan kelebihan energinya untuk mensintesis protein. Pada saat kematangan fisik terjadi, biasanya jumlah lemak tubuh remaja perempuan dua kali lebih banyak daripada lakilaki. Penimbunan lemak ini terjadi di daerah sekitar panggul, payudara, dan lengan atas. Penelitian ini juga sesuai dengan penelitian yang dilakukan oleh Dwipayani \& Prajaskari $(2018)^{5}$ juga menyatakan bahwa status gizi berat badan berlebih dan obesitas didapatkan lebih tinggi pada perempuan dibandingkan laki-laki.

Berdasarkan hasil penelitian yang dilakukan dengan cara mengukur IMT responden didapatkan responden dengan derajat obesitas 1 berjumlah 42 orang dan obesitas derajat 2 berjumlah 29 orang dan paling tinggi ditemukan pada usia 17 tahun. Hal ini kemungkinan dikarenakan pola hidup pada remaja yang masih terpengaruh lingkungan dan sering mengkonsumsi makanan cepat saji (fastfood) dan juga mungkin dikarenakan kebiasaan hidup yang sedentary life. Berdasarkan Riset Kesehatan Dasar (Riskesdas) 2007 hingga 2013 menyebutkan prevalensi obesitas pada kelompok umur 16-18 tahun adalah sebanyak 7,3\%. ${ }^{6}$ Penelitian yang dilakukan oleh Sartika $(2011)^{19}$ menunjukkan tinggi nya asupan energi pada remaja obesitas mungkin dikarenakan konsumsi makanan cepat saji yang menjadi kebiasaan umum baik di kota besar maupun kecil di wilayah Indonesia. Secara umum, komposisi makanan jenis makanan cepat saji adalah tinggi energi, lemak, garam dan rendah serat.

Penelitian yang dilakukan oleh Mustelin (2009) ${ }^{13}$ menunjukkan bahwa anak yang tidak berolahraga memiliki risiko obesitas sebesar 1,35 kali dibandingkan dengan anak yang rutin berolahraga. Selain itu ternyata anak yang tidak rutin berolahraga justru cenderung memiliki asupan energi yang lebih tinggi dibandingkan anak yang rutin berolahraga. Makanan 
dan aktivitas fisik dapat mempengaruhi timbulnya obesitas baik secara bersama maupun masing-masing.

Berdasarkan hasil penelitian ini didapatkan bahwa dari 71 responden obesitas, didapatkan subjek penelitian yang memiliki risiko tinggi sebanyak 39 orang dan yang memiliki risiko rendah sebanyak 32 orang. Hal ini dikarenakan obesitas merupakan salah satu faktor risiko untuk terjadinya obstructive sleep apnea. Obesitas dapat mengubah volume dan bentuk anatomi, lidah dapat terangkat sehingga mengurangi volume saluran napas atas. ${ }^{17}$ Pada saat inspirasi, otot dilator faring berkontraksi terlebih dulu sebelum otot diafragma berkontraksi, sehingga lumen faring tidak kolaps akibat tekanan sssssintrafaring yang negatif oleh karena kontraksi otot dinding dada dan diafragma. Pada orang yang obesitas Pada waktu tidur akitivitas otot dilator faring relatif tertekan (relaksasi), sehingga lumen faring cenderung menyempit saat inspirasi. ${ }^{10}$

Pada orang yang obesitas terdapat penyempitan saluran nafas bagian atas akibat penimbunan jaringan lemak di dalam otot dan jaringan lunak di sekitar saluran nafas, maupun kompresi eksternal leher dan rahang. Diduga bahwa penumpukan lemak pada daerah leher dapat membuat saluran nafas atas menjadi lebih sempit. Kemungkinan lain adalah pada pasien obesitas mempunyai velofarings yang lebih mudah mengalami kolaps sehingga dapat mempermudah terjadinya sumbatan saluran nafas atas pada waktu tidur. ${ }^{3}$ Hal ini sesuai dengan penelitian Rahman et al (2012) ${ }^{16}$ yang menyatakan bahwa remaja yang obesitas memliki risiko tinggi obstructive sleep apnea.

Hasil analisis bivariat menggunakan uji sommers'd mengenai korelasi derajat obesitas dengan risiko terjadinya obstructive sleep apnea pada remaja SMA, didapatkan nilai P sebesar 0,000 dengan tingkat kepercayaan $(\alpha)$ yaitu 0,05 yang berarti terdapat korelasi antara derajat obesitas dengan risiko terjadinya obstructive sleep apnea pada remaja SMA di kecamatan Banda Sakti Kota Lhokseumawe. Hal ini mungkin disebabkan karena obesitas dapat menyebabkan akumulasi jaringan lemak pada leher dan saluran napas bagian atas sehingga menurunkan diameter saluran napas yang merupakan predisposisi terjadinya penutupan saluran napas atas saat jaringan otot relaksasi selama tidur. ${ }^{1}$ Hasil penelitian ini juga menunjukkan bahwa semakin tinggi derajat obesitas maka semakin tinggi risiko terjadinya obstructive sleep apnea, hal ini sejalan dengan penelitian yang dilakukan oleh Bambang et al (2005) ${ }^{1}$ juga menyatakan anak dengan obesitas 2,1 kali lebih besar mengalami risiko obstructive sleep apnea.

Hasil penelitian ini juga sesuai dengan penelitian yang dilakukan oleh Suryawan $(2016)^{21}$ yang mengatakan terdapat hubungan antara obesitas dengan risiko menderita 
obstructive sleep apnea. Saat ini, obesitas merupakan penyebab utama OSA pada anak-anak di negara-negara barat karena peningkatan prevalensi obesitas yang tinggi pada anak-anak. Sebuah studi epidemiologi besar menunjukkan bahwa obesitas adalah faktor risiko paling signifikan untuk mengembangkan OSA pada anak-anak antara 2 dan 18 tahun. ${ }^{2}$

Penelitian ini juga sejalan dengan penelitian yang dilakukan oleh Rahman et al (2012) ${ }^{16}$ menunjukkan terdapat hubungan antara obesitas dengan risiko terjadinya obstructive sleep apnea, hal ini mungkin dikarenakan akumulasi jaringan lemak dapat mengganggu fungsi ventilasi pada orang dewasa dan anak-anak. Peningkatan BMI biasanya berhubungan dengan penurunan volume ekspirasi paksa dalam satu detik (FEV1), kapasitas vital paksa (FVC), kapasitas total paru, kapasitas residu fungsional dan volume cadangan ekspirasi. Secara klinis terjadi pola restriksi (kapasitas total paru $<85 \%$ prediksi) biasanya ditemukan pada obesitas besar, pada rasio berat terhadap tinggi badan adalah 0,9 sampai $1,0 \mathrm{~kg} / \mathrm{m}$ atau lebih besar. Namun, kelainan restriksi masih mungkin ditemukan pada obesitas dengan rasio berat badan terhadap tinggi kurang dari $0,9 \mathrm{~kg} / \mathrm{cm}$. ini biasanya terjadi dengan adanya penumpukan lemak sentral, yang ditandai dengan rasio pinggang-pinggul 0,95 lebih. ${ }^{12}$

\section{KESIMPULAN}

Berdasarkan hasil penelitian dan pembahasan, didapatkan kesimpulan hasil penelitian ini adalah responden yang mengalami obesitas adalah sebanyak 71 orang dengan laki-laki berjumlah 30 orang dan perempuan berjumlah 41 orang, dan responden yang mengalami obesitas derajat 1 berjumlah 42 orang dan responden yang mengalami obesitas derajat 2 berjumlah 29 orang, dan didapatkan responden yang memiliki risiko rendah berjumlah 32 orang dan yang memiliki risiko tinggi berjumlah 39 orang, dan $\mathrm{p}=0,000$ sehingga Terdapat korelasi antara derajat obesitas dengan risiko terjadinya obstructive sleep apnea pada remaja SMA Negeri di Kecamatan Banda Sakti Kota Lhokseumawe tahun 2018.

\section{REFERENSI}

1. Bambang, S et al 2005. Characteristics And Risk Factors Of Snoring And The Prevalence Of Suspected Obstructive Sleep Apnea In Children. Jurnal Paediatrica Indonesia, Volume 45 No.1, 158-161.

2. Chang, S. J. dan Chae, K. Y. 2010. Obstructive Sleep Apnea Syndrome In Children: Epidemiology, Pathophysiology, Diagnosis And Sequelae. Korean Journal of Pediatrics, Volume 53, No.10, 863-871.

3. Chouri-Pontarollo, N et al. 2005. Obstructive Sleep Apnea Syndrome Pada Anak. Jurnal Sari Pediatri, Volume 7, No. 2, 77-84. 
4. Dinkes 2017. Data Status Obesitas Pada Anak sekolah tahun 2017. Lhokseumawe, Dinas Kesehatan Kota Lhokseumawe.

5. Dwipayana, I.M.P 2018. Perbedaan Prevalensi Obesitas Dan Berat Badan Lebih Pada Siswa Sekolah Menengah Atas (SMA) Negeri Antara Daerah Urban Dan Rural Di Kabupaten Gianyar. E-jurnal Medika, Volume 7, No. 2, 72-76.

6. Hastoety, S et al 2017. Metaanalisis: Pencegahan Obesitas pada Anak Sekolah. Jurnal Media Litbangkes, Volume 27, No.1, 39-48.

7. Humayrah, W. 2009. Faktor Gaya Hidup Dalam Hubungannya Dengan Risiko Kegemukan Orang Dewasa Di Provinsi Sulawesi Utara, Dki Jakarta, Dan Gorontalo. Bogor, Fakultas Ekologi Manusia Institut Pertanian Bogor.

8. Kussoy, K. Fatimawali dan Kepel, B 2013. Prevalensi Obesitas pada Remaja di Kabupaten Minahasa. Jurnal e-Biomedik (eBM), Volume 1, No.2, 981-985.

9. Luman, A. 2016. Obstructive Sleep Apnea (OSA) pada DM Tipe 2. Jurnal Cermin Dunia Kedokteran, Volume 43, No.2, 96-100.

10. Marbun, E. M. (2011). Mendengkur, Jakarta, Fakultas Kedokteran Universitas Kristen Krida Wacana.

11. Mexitalia, M et al 2009. Sindroma Metabolik pada Remaja Obesitas. Jurnal Media Medika Indonesia, Volume 43, No.16, 300-306.

12. Mukhlis, M dan Arif, B 2015. Obstructive Sleep Apnea (OSA), Obesitas Hypoventilation syndrome (OHS) Dan Gagal Napas. Jurnal Respirasi, Volume 1, No. 3, 94-102.

13. Mustelin, L et al 2009. Physical Activity Reduces The Influence Of Genetic Effects On BMI And Waist Circumference. Internasional Jurnal Of Obesity, Volume 33, No.1, 29-36.

14. Oktaviani, W.W. Saraswati, L.D 2012. Hubungan Kebiasaan Konsumsi Fast Food, Aktivitas Fisik, Pola Konsumsi, Karakteristik Remaja Dan Orang tua Dengan Indeks Massa Tubuh. Jurnal Kesehatan Masyarakat, Volume 1, No.2, 542-553.

15. Prasetya, D 2016. Sindrom OSA pada Anak. Jurnal Cermin Dunia Kedokteran, Volume 43, No.2, 101-105.

16. Rahman, U. B. Handoyo, dan Rohadi, P 2012. Hubungan Obesitas dengan Risiko Obstructive Sleep Apnea (OSA) pada Remaja. Jurnal Ilmiah Kesehatan Keperawatan, Volume 8, No.1, 44-56.

17. Rasjid, M. dan Yogiarto, M 2015. Obstructive Sleep Apnea ( OSA ), Medika Tadulako, Jurnal Ilmiah Kedokteran, Volume 2, No.3, 9-12.

18. Sajawandi, L. 2015. Pengaruh Obesitas pada Perkembangan Siswa Sekolah Dasar dan Penanganannya dari Pihak Sekolah dan Keluarga. Universitas Muhammadiyah Purwokerto.

19. Sartika, R. A. D 2011. Faktor Risiko Obesitas pada Anak 5-15 Tahun di Indonesia. Jurnal Makara kesehatan, Volume 15, No.1, 37-43.

20. Setiawan, M 2010. Nutrisi Kedelai Pada Obesitas Dan Dismetabolik Sindrom, Malang, Universitas Muhammadiyah Malang.

21. Suryawan, P dan Tirtayasa, K 2016. Hubungan Antara Obesitas Dengan Risiko Menderita Gangguan Tidur Obstructive Sleep Apnea. Bali, Fakultas Kedokteran Universitas Udayana.

22. Wahyu, G. G. 2009. Buku Obesitas Pada Anak. Edisi : 1, halaman 7-9. Yogyakarta, Benteng Pustaka. 
